\title{
RADIO SIARAN PUBLIK SEBAGAI MEDIA KOMUNIKASI PERGURUAN TINGGI DALAM PEMBERDAYAAN MASYARAKAT PERDESAAN
}

\author{
Wisnu Widjanarko, Muhammad Sulthan, Yusida Lusiana \\ Fakultas Ilmu Sosial dan Ilmu Politik Universitas Jenderal Soedirman
}

\begin{abstract}
ABSTRAK
Eksistensi perguruan tinggi adalah sejauh dirinya tidak membatasi diri sebagai wahana pengembangan ilmu pengetahuan belaka, melainkan mampu menghasilkan sebesar-besarnya kemaslahatan bagi masyarakat Salah satunya adalah melalui diseminasi teknologi tepat guna bagi masyarakat perdesaan yang merupakan representasi yang tidak dapat dibantah lagi dalam demografi Indonesia. Proses diseminasi tersebut diharapkan mampu mengukuhkan keberadaan institusi perguruan tinggi sebagai pusat pendidikan, penelitian dan pengabdian masyarakat. Menggunakan metode reception analysis, penelitian ini menggunakan siaran Mimbar IPTEKS kerjasama LPPM UNSOED dan RRI Purwokerto sebagai objek penelitian. Hasil penelitian menunjukkan, bahwa siaran Mimbar IPTEKS telah menjadi media transformasi informasi berbasis transmisi, interaksi dan transaksi. Namun demikian, hasil penelitian juga menunjukkan bahwa perlunya meningkatkan kemampuan narasumber dalam menggunakan diksi yang disesuaikan dengan frame of reference dan field of experience masyarakat perdesaan sehingga efektivitas pemahaman dapat lebih terakselerasi
\end{abstract}

Kata-kata kunci: Radio penyiaran, perguruan tinggi, pemberdayaan masyarakat perdesaan

\section{PUBLIC BROADCASTING RADIO AS HIGHER EDUCATION COMMUNICATION MEDIA OF RURAL COMMUNITY EMPOWERMENT}

\begin{abstract}
The existence of universities in society is not only take part as a vehicle for the development of science, but also as a place of science and technology deployment for the benefit of society. The main effort in reaching university existence in society are by using dissemination of information of technology for rural communities. Rural communities represent a significant area in the Indonesian demographic. The technology dissemination process is expected to establish the presence of higher education institutions as centers of education, research and community service. Using the method of reception analysis, this study uses Mimbar IPTEKS broadcasting in cooperation with RRI Purwokerto and LPPM UNSOED as the object of research. The results showed, that Mimbar IPTEKS broadcasting has become a media of information transformation, interaction and transaction. However, the results also indicate that the broadcast needs the improvement of speakers ability to use the diction adapted to the frame of reference and experience in the rural communities so they could understand and accept an effective comprehension whice later can be accelerated.
\end{abstract}

Keywords: Radio broadcasting, higher education, rural community empowerment

Korespondensi: Dr. Wisnu Widjanarko. Fakultas Ilmu Sosial dan Ilmu Politik Universitas Jenderal Soedirman, Jl. Prof. H.R. Boenyamin No. 993 Purwokerto, Jawa Tengah 53122. Email: wisnu_widj@yahoo.com 


\section{PENDAHULUAN}

Pemberdayaan masyarakat perdesaan adalah sebuah proses untuk membuat dirinya berada dalam kapasitas yang mampu menemukan sumberdaya yang ada di sekitarnya sebagai elan vital dalam kehidupannya. Data dari BPS RI menunjukkan hingga Maret 2012, tercatat dari 29,13juta jiwa orang miskin di Indonesia, 18,48 juta jiwa atau $63,4 \%$ berada di perdesaan (Beritasatu, 2013). Jamal (2009) mengungkapkan, bahwa untuk mempercepat pembangunan di perdesaan dibutuhkan partisipasi aktif di mana masyarakat merupakan penggerak utamanya. Namun, untuk memandirikan masyarakat dibutuhkan suatu kapasitas masyarakat yang mandiri dan mampu memberdayakan dirinya. Realitas ini diakui bukanlah hal yang mudah. Masyarakat di perdesaan belum memiliki kecakapan dalam mengelola produktivitas, efisiensi, mutu dan kontinuitas pasokan yang terus menerus meningkat, terpelihara serta berkualitas tinggi.

Namun demikian, tidaklah mudah dalam proses diseminasi teknologi tepat guna. Mizar, dkk (2008) memaparkan bahwa pengetahuan seseorang sangat mempengaruhi teknologi yang akan dimanfaatkan serta intensitas informasi dan jenis komunikasi yang digunakan dalam mengakses teknologi tersebut.

Hal senada diungkapkan oleh Hadi (1999) di mana seringkali terjadi kegagalan ketika kesalahan pendekatan dari sistem sumber dalam komunikasi pembangunan karena mengabaikan personalitas petani, perubahan perilaku petani, proses pengambilan keputusan inovasi dan pengaruhnya terhadap penerapan inovasi teknologi. Padahal, sektor pertanian memainkan peranan penting, karena peranannya sebagai penghasil pangan utama, lapangan kerja sebagian besar penduduk, pemasok bahan untuk industri, penghasil devisa negara dengan kandungan impor rendah, mempunyai efek multiplier yang tinggi, kegiatan yang ramah lingkungan, penghasil energi alternatif (biofuel) serta menjadi basis utama terjaganya ketahanan pangan.

Salah satu institusi penyedia teknologi adalah lembaga perguruan tinggi, karena mandat yang dibebankannya tidak hanya menyelenggarakan kegiatan pembelajaran dan riset belaka, melainkan juga bagaimana keberadaannya memberikan makna bagi masyarakat. Universitas Jenderal Soedirman (UNSOED) adalah satu lembaga perguruan tinggi yang memfokuskan diri pada pengembangan sumber daya perdesaan berkelanjutan. Sebagai perguruan tinggi negeri di bawah administrasi Kementerian Pendidikan dan Kebudayaan RI, sejak tahun 1963 hingga kini, UNSOED tidak pernah bergeser dari pengembangan perdesaan yang mewujud pada visi, misi, tujuan pengembangan, rencana strategis dan rencana induk pengembangan pada penelitian dan pengabdian masyarakat (Widjanarko, 2012).

Guna memastikan bahwa seluruh inovasi dan invensi memiliki kebermaknaan di masyarakat perdesaan, maka diperlukan suatu pola komunikasi yang efektif, efisien, berdayaguna serta berhasil guna. Pemanfaatan media massa adalah sarana yang memiliki kemampuan komunikatif dalam menjangkau khalayak secara massal (Mc Quaill, 2004). Yusouf, Ibrahim \& Amizah (2012) mengungkapkan bahwa pembangunan pertanian salah satunya dapat ditingkatkan melalui peranan radio sebagai media efektif dalam meningkatkan pengetahuan dan pemahaman masyarakat di bidang pertanian. Hal ini senada dengan riset yang dilakukan oleh Mulyandari, Saleh \& Dadan (2010) di mana radio dalam konteks pertanian dan pembangunan perdesaan dapat memfasilitasi penyediaan informasi tentang dunia agribisnis serta perkembangan IPTEKS pertanian, berperan sebagai media komunikasi antar masyarakat pertanian, menjadi media pembelajaan dan hiburan yang sesuai dengan kebutuhan komunitas pertanian, membangun komunitas agribisnis yang kaya dan menjadi sumber informasi bagi seluruh masyarakat yang membutuhkannya serta mempercepat pelaksanaan pembangunan pertanian.

Dalam kerangka ini, maka dibutuhkan suatu model komunikasi yang memberdayakan masyarakat perdesaan dengan menjalin kemitraan dengan lembaga penyiaran publik. Sejatinya, sejak tahun 2006, UNSOED telah bekerjasama dengan Lembaga Penyiaran Publik (LPP) Radio Republik Indonesia (RRI) Stasiun Purwokerto dalam penyebarluasan IPTEKS yang terkait dengan pembangunan perdesaan melalui dialog interaktif bersama para akademisi yang memiliki kompetensi di bidangnya. Namun demikian, kemitraan tersebut masih sebatas dalam ruang diskursus yang belum teridentifikasi sejauh mana efektivitas dan kebermaknaan informasi bagi pihak-pihak yang terkait, khu- 
susnya pada pola komunikasi organisasi dalam hal ini perguruan tinggi dengan publik sebagai wujud akuntabilitasnya.

Dari perspektif keilmuan, riset ini akan memperkaya kajian komunikasi yang berorientasi pada pembangunan dan pemberdayaan masyarakat. Perspektif transaksional, akan mengintegrasikan antara revitalisasi fungsi komunikasi massa, public relations atau kehumasan dengan proses pemandirian dan pemberdayaan masyarakat. Pengintegrasian ini menjadi penting karena semua elemen yang terlibat dalam riset ini, yakni perguruan tinggi sebagai penyedia informasi, lembaga penyiaran publik sebagai kanal diseminasi dan masyarakat sebagai pengguna informasi berada dalam kesetaraan dalam upaya membangun kesepahaman makna bersama dalam proses pemberdayaan masyarakat.

Selain itu, penelitian ini tidak hanya berkutat dalam pemahaman teoretis belaka melainkan juga memberikan manfaat bagi seluruh pemangku kepentingan yang terlibat dalam hal ini. Melalui diseminasi informasi tentang teknologi tepat guna diharapkan akan mempercepat proses adopsi teknologi yang bermuara pada kemampuan masyarakat perdesaan mengelola sumberdaya yang berada di perdesaan itu sendiri.

Bagi insitusi perguruan tinggi, dalam hal ini UNSOED, proses diseminasi selain mewujud sebagai bentuk akuntabilitas kinerja sebagai lembaga yang dimandatkan sebagai pusat pengembangan IPTEKS berbasis riset juga dapat meningkatkan kredibilitas dan akseptabilitas bagi publik. Sedangkan bagi RRI, sebagai lembaga penyiaran publik, peran yang dilakukan sebagai kanal informasi, dapat meningkatkan fungsinya sebagai media diseminasi yang berpihak pada kepentingan masyarakat perdesaan.

Beranjak dari latar belakang di atas, maka kemudian lahir sejumlah pertanyaan, apakah perguruan tinggi telah berperan sebagai komunikator atas inovasi dan invensi teknologi tepat guna? Apakah lembaga penyiaran publik telah berperan sebagai kanal diseminasi informasi bagi masyarakat? Apakah masyarakat perdesaan yang menjadi pendengar juga telah memanfaatkan informasi tersebut guna mempercepat kualitas kesejahterannya?

Beranjak dari pemahaman tersebut, bagaimana sesungguhnya model komunikasi perguruan tinggi dengan publik dalam mendiseminasikan teknologi tepat guna bagi masyarakat perdesaan? Sejauhmana masyarakat perdesaan merasakan kemanfaatan proses diseminasi melalui media penyiaran? Bagaimana proses dinamika adopsi teknologi tepat guna berlangsung melalui media komunikasi penyiaran berbasis pendengar berlangsung?

Tujuan penelitian ini adalah melahirkan sebuah model komunikasi perguruan tinggi dalam memberdayakan masyarakat perdesaan melalui diseminasi teknologi tepat guna berbasis media massa penyiaran publik. Model ini ditujukan untuk meningkatkan kapasitas perguruan tinggi dalam memastikan eksistensinya sebagai pusat pengembangan dan persemaian ilmu pengetahuan yang berorientasi pada kemaslahatan, kemandirian dan kesejahteraan masyarakat.

Selain itu, model ini ditujukan untuk menemukan formula komunikasi strategis yang melibatkan para pemangku kepentingan dalam proses pembangunan dan pemberdayaan masyarakat, yakni institusi perguruan tinggi sebagai penyedia inovasi dan invensi teknologi tepat guna, lembaga penyiaran publik sebagai kanal diseminasi informasi dan masyarakat sebagai pengguna informasi terkait teknologi tepat guna perdesaan.

\section{METODE PENELITIAN}

Penelitian dilaksanakan pada Bulan Juli s.d Oktober 2013 dengan mitra dari Lembaga Penyiaran Publik Radio Republik Indonesia (LPP-RRI) Purwokerto serta kelompok pemerhati siaran Mimbar Teknologi yang berasal dari wilayah Kabupaten Banyumas.

Data primer berasal dari transkripsi materi siaran Mimbar Teknologi serta diskusi pemerhati siaran tersebut yang dilakukan melalui $f_{o-}$ cus group discussion. Sedangkan data sekunder berasal dari referensi terkait melalui studi kepustakaan.

Metode yang digunakan adalah reception analysis approach yang dilakukan melalui sejumlah tahapan, yakni preferred reading melalui tekstualisasi materi siaran yang diidentifikasi struktur internalnya. Selanjutnya, hasil wawancara dan FGD yang telah ditranskripsi dikategorisasi berdasarkan klasifikasi interpretasi antara subjek berdasarkan pemaknaan yang muncul atas kegiatan diseminasi melalui siaran 
radio tersebut. Tahapan berikutnya adalah menganalisis kategorisasi dengan mempertimbangkan karakteristik informan khususnya terkait dengan frame of reference dan field of experience terhadap perdesaan. Selanjutnya, analisis secara kategoris tadi dikomparasi dengan preferred reading sehingga teridentifikasi bahwa pemaknaan audiens berada pada kelompok dominant, oppositional atau negotiated reading atas informasi yang dikomunikasikan kepadanya.

\section{HASIL DAN PEMBAHASAN}

Universitas Jenderal Soedirman (UNSOED) adalah perguruan tinggi negeri di bawah administrasi Kementerian Pendidikan dan Kebudayaan RI yang didirikan berdasarkan Keputusan Presiden RI No. 195 Tahun 1963 tertanggal 23 September 1963. Perguruan tinggi ini memfokuskan diri pada pengembangan IPTEKS berbasis sumberdaya perdesaan dan penggalian serta pemanfaatan kearifan lokal serta diimplementasikan melalui tridharma perguruan tinggi, yakni pendidikan, penelitian dan pengabdian kepada masyarakat. Salah satu karakteristik universitas tersebut adalah berbasis riset, artinya seluruh proses pendidikan dan implementasinya harus berlandaskan kegiatan penelitian.

Tidak hanya itu, universitas juga berkewajiban dalam tugas-tugas pengabdian kepada masyarakat, baik dalam diseminasi maupun aplikasinya, harus berdasarkan dari hasil-hasil penelitian. Dalam konteks UNSOED, seluruh fokus pengembangan sains dan teknologi diorientasikan pada pengembangan sumberdaya perdesaan sehingga selaras dengan tujuan universitas, yakni menjadi pusat unggulan pemberdayaan perdesaan dan sasaran dan meningkatkan kapasitas universitas dalam penguasaan, invensi, dan inovasi IPTEKS untuk memecahkan permasalahan kehidupan manusia.

Salah satu wilayah perdesaan di Indonesia yang juga merupakan lumbung pangan nasional, adalah Kabupaten Banyumas, Jawa Tengah. Berada di 108039 '17' - 109027 '15" Bujur Timur dan 7015 '05” - 7037 '10” Lintang Selatan, kabupaten ini, memiliki luas 132/759 Ha di mana 24,68\% areanya adalah lahan persawahan. Karakteristik perdesaan juga terlihat dari struktur kepemerintahannya, di mana terdapat 301 desa dari 331 pemerintahan setingkat desa dan kelurahan. Selain itu, sektor pertanian memberi kontribusi terbesar pada Produk Domestik Regional Bruto. Namun demikian, realitas juga menunjukkan bahwa sektor pertanian tengah mengalami penurunan di mana luas panen dan produktivitas tanaman pangan mengalami penurunan (Kabupaten Banyumas, 2012). Dengan kata lain, ketika suatu daerah mulai mengalami penurunan pada kuantitas bahkan kualitas pertaniannya, tidak dapat dipungkiri akan berdampak pada ketahanan pangan di daerah tersebut.

LPP RRI sebagai mitra UNSOED dalam proses mendiseminasi hasil-hasil penelitian sejalan dengan peranannya sebagai media penyiaran publik. Berdiri pada 11 September 1945, RRI saat ini telah bertransformasi menjadi lembaga penyiaran publik dari institusi pemerintah sebagaimana diatur dalam UU No. 32 Tahun 2002 tentang Penyiaran, PP No. 11 Tahun 2005 tentang Penyiaran Lembaga Penyiaran Publik dan PP No. 12 tentang Lembaga Penyiaran Publik Radio Republik Indonesia.

Tugas pokok LPP RRI adalah memberikan pelayanan informasi, pendidikan, hiburan yang sehat, kontrol dan perekat sosial serta melestarikan budaya bangsa untuk kepentingan seluruh lapisan masyarakat melalui penyelenggaraan penyiaran radio yang menjangkau seluruh wilayah NKRI. Kesamaan persepsi untuk dapat berpartisipasi aktif dan berkontribusi dalam peningkatan kualitas masyarakat antara UNSOED dengan LPP RRI, khususnya LPP RRI Purwokerto selanjutnya dituangkan dalam kemitraan, khususnya dalam publikasi informasi, siaran pendidikan penelitian dan pengabdian masyarakat, pengembangan sumberdaya manusia dan budaya lokal. Dalam konteks pengembangan sumberdaya perdesaan, kemitraan dalam siaran Mimbar IPTEKS diharapkan akan menghasilkan mediasi hasil-hasil kepakaran para akademisi dengan masyarakat, yang muaranya adalah pada percepatan kemandirian dan kesejahteraan masyarakat berbasis pada potensi yang dimiliki masyarakat.

Hasil penelitian menunjukkan bahwa Mimbar IPTEKS yang merupakan kemitraan antara LPPM UNSOED dengan LPP RRI UNSOED terdiri dari 3 (tiga) kategori siaran, yakni $a p$ likasi teknologi untuk perdesaan, peningkatan kualitas kesehatan perdesaan dan sosial humaniora perdesaan. Aplikasi teknologi melip- 
suti dimensi agroteknologi, rekayasa pertanian, produksi ternak, pengelolaan sumber daya hayati dan lingkungan. Dimensi sosial humaniora meliputi dimensi penegakkan hukum, pemahaman administrasi pemerintah daerah dan pengelolaan komunikasi publik sedangkan terkait peningkatan kualitas kesehatan masyarakat, meliputi pemanfaatan obat-obatan.

Selain itu, UNSOED juga telah menjalankan kebijakan yang telah ditetapkan dalam Renstra 2011-2020 yakni meningkatkan diseminasi karya IPTEKS melalui publikasi kepada masyarakat akademik serta pengguna, dalam hal ini melalui siaran Mimbar IPTEKS yang dikonsumsi oleh masyarakat perdesaan di wilayah sekitar kampus. Konten siaran meliputi dialog yang bersentuhan dengan isu-isu strategis di perdesaan, seperti masalah pangan dan lingkungan yang layak, kasus kematian ibu dan anak serta gizi buruk, meningkatkan nilai tambah keekonomian dari potensi lokal, serta kesadaran akan pengelolaan layanan publik di desa yang berkualitas. Materi yang disampaikan dalam format dialog ini, semuanya menyentuh pada kebutuhan masyarakat perdesaan dengan mengoptimalkan peranan akademisi tidak hanya sebagai seorang pengajar dan peneliti, melainkan juga memiliki tanggung jawab sosial kepada masyarakat di sekelilingnya.

Proses tanggung jawab dalam diseminasi teknologi, sesungguhnya diartikulasikan dalam proses edukasi masyarakat melalui konsep transmisi, interaksi dan transaksi informasi IPTEKS perdesaan. Transmisi mewujud dalam konsep narasumber yang berusaha mengidentifikasi permasalahan yang ada di masyarakat, kemudian mencoba membangun konstruksi berpikir untuk kemudian menemukan solusi bijak yang disajikan berdasarkan konsep-konsep teoretis yang dapat diimplementasikan di masyarakat. Interaksi dimanifestasikan dalam bentuk ketersediaan umpan balik dalam proses komunikasi antara narasumber dengan audiens dan transaksi terjadi ketika kedua belah pihak berupaya untuk membangun kesepahaman makna dalam perannya masing-masing sehingga upaya dalam menjawab permasalahan yang dihadapi masyarakat.

Masyarakat yang mengakses informasi IPTEKS melalui radio merasakan banyak hal baru yang diterima dan memberikan inspirasi bagi mereka dalam mengembangkan kualitas diri, khususnya kemandirian serta kesejateraannya. Namun, penelitian juga menemukan bahwa dalam proses diseminasi, narasumber ternyata masih dinilai menggunakan diksi yang kurang

\section{Model Pemberdayaan Berbasis Diseminasi Teknologi Tepat Guna Melalui Radio Siaran Publik}

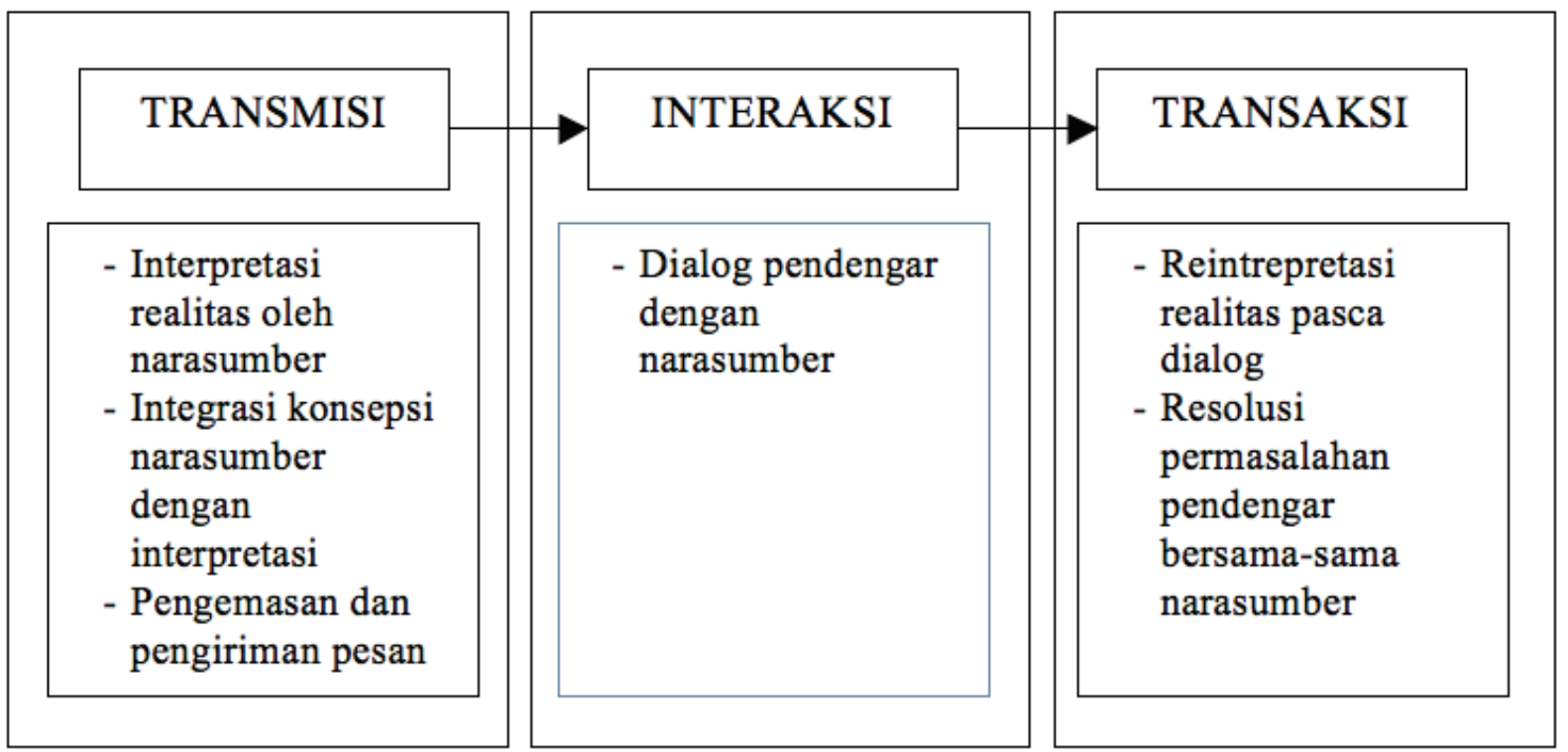


bersentuhan dengan keseharian. Hal ini terjadi karena para narasumber lebih banyak menggunakaan istilah-istilah akademis yang perlu diterjemahkan menjadi istilah yang lebih dimengerti masyarakat.

\section{SIMPULAN}

Radio sebagai media siaran publik memiliki peranan besar dalam mengkomunikasikan ide, gagasan, produk dan aplikasi teknologi yang dihasilkan perguruan tinggi kepada masyarakat. Proses komunikasi meliputi dimensi transmisi, interaksi dan transaksi informasi yang dapat meningkatkan kemandirian masyarakat di perdesaan dalam mengelola dinamika dan problematika. Transmisi informasi hanya terjadi ketika narasumber melakukan interpretasi terhadap realitas keseharian masyarakat sekaligus diintegrasikan dengan konsepsi IPTEKS dan teknologi tepat guna yang dikuasai untuk kemudian diterjemahkan dalam bentuk pesan kepada pendengar. Interaksi berlangsung manakala narasumber bersedia membangun dialog dan pendengar secara terbuka menyampaikan problematika yang ada untuk kemudian terjadi proses transaksi informasi di mana kedua belah pihak berusaha untuk mencari titik pandang yang dipahami bersama sebagai solusi atas permasalahan yang dihadapi oleh pendengar sebagai masyarakat untuk kemudian lebih mampu memberdayakan dirinya.

Namun demikian, guna meningkatkan efektivitas proses diseminasi, dibutuhkan kemampuan para komunikator untuk memodifikasi pesan sesuai dengan dunia kesehariannya. Kegagalan terbesar dalam proses diseminasi adalah terjebaknya narasumber pemilik teknologi tepat guna atau konsep untuk sebuah solusi bagi masyarakat dalam terminologi atau diksi yang terikat dengan aturan saintifik yang kaku. Padahal, tugas terbesar setelah sebuah penelitian berhasil dilakukan adalah menerjemahkan kembali dalam kerangka manfaat bagi masyarakat yang disesuaikan dengan paradigma pemikiran dan kebiasaan dari masyarakat itu sendiri.

Untuk meningkatkan proses transaksi informasi sebagai muara dari diseminasi yang berorientasi pada pemberdayaan masyarakat, maka narasumber perlu memahami dimensi sosiologis, antropologis dan psikologis pendengar, dalam hal ini masyarakat perdesaan. Hal ini penting mengingat suatu pesan, gagasan, ide bahkan aplikasi untuk sebuah solusi hanya akan menjadi sebuah kesia-siaan belaka manakala gagal ditransformasikan dalam bingkai pemahaman masyarakat menerima pesan tersebut.

\section{DAFTAR PUSTAKA}

Beritasatu. (2013). BPS: penduduk miskin berkurang 540 ribu jiwa. Diakses dari http:// www.beritasatu.com/ekonomi/90316-bpspenduduk-miskin-berkurang-540-ribu-jiwa. html

Hadi, A. P. (1999). Strategi komunikasi dalam mengantisipasi kegagalan penerapan teknologi oleh petani. Journal of Rural Studies, 2(2) : 48-57

Jamal, E. (2009). Membangun momentum baru pembangunan pedesaan di Indonesia. Jurnal Litbang Pertanian, 28(1) : 7-13

Kabupaten Banyumas. (2012). Banyumas dalam angka 2012. Diakses dari http:// www.banyumaskab.go.id/read/1206/banyumas-dalam-angka-2012\#.U1c7LKIY6sU

Mc Quaill, D. (2004). Teori komunikasi massa. Erlangga, Jakarta

Mizar, M.A., et.al. (2008). Tipologi dan karakteristik adopsi teknologi pada industri kecil pengolah pertanian, Prosiding Seminar Nasional Teknik Pertanian, UGM, Yogyakarta

Mulyandari, R.S.H., Saleh, A., Dadan. (2010). Revitalisasi radio pertanian Ciawi (RPC) sebagai pusat informasi pembangunan pertanian, Informatika Pertanian 19 (1): 69-90

Yusouf, F., Ibrahim, F., Amizah, W. (2012). Agricultural radio talks and drama: malaysia early development experience, Malaysia Journal of Communication, 28 (1): 77-88

Widjanarko, W., et.al. (2012). Inventarisasi teknologi tepat guna sebagai basis promosi institusi perguruan tinggi: studi di Universitas Jenderal Soedirman, Laporan Penelitian, Pusat Pengembangan Teknologi LPPM UNSOED, Purwokerto 